\title{
Efter- og videreuddannelsesaktiviteter på FSKK på CBS
}

\author{
Henrik Køhler Simonsen \\ Adjunkt, ph.d., erhvervsforsker \\ Engelsk Institut \\ Copenhagen Business School \\ hks.eng@cbs.dk \\ www.telelex.dk
}

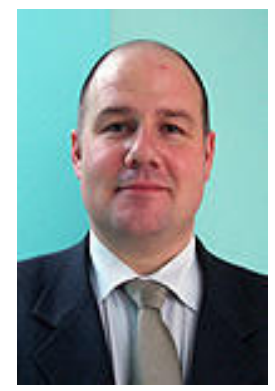

Henrik Køhler Simonsen er adjunkt ved Engelsk Institut, Copenhagen Business School (CBS) og forsker i virksomhedsleksikografi. Henrik Køhler Simonsen underviser i engelsk virksomhedskommunikation, web communication, technical communication, corporate language policy samt IT og har stor erfaring med anvendelse af IT og sprogteknologi i undervisning, forskning og praksis. Henrik Køhler Simonsen er desuden studieleder for Efter- og Videreuddannelse på Fakultetet for Sprog, Kultur og Kommunikation (FSKK) på CBS.

\section{Indledning og problem}

Den moderne vidensmedarbejder har behov for bedre og mere fleksibel efter- og videreuddannelse. Og der er meget, der tyder på, at dette behov kun vil blive endnu mere udtalt, når efter- og videreuddannelse måske kommer på dagsordenen i forbindelse med næste års overenskomstforhandlinger. Og da Danmark i globaliseringen formentlig aldrig vil kunne konkurrere på lave lønninger, må og skal vi som samfund satse på viden - og dermed mere efter- og videreuddannelse. Efter- og videreuddannelse er da også vigtigt for 9 ud af 10 danskere, jf. en Gallup-undersøgelse udført for Ugebrevet A4, jf. Madsen \& Redder (2006) og Politiken.dk (2006).

Udfordringen for udbyderne af efter- og videreuddannelse er at finde på flere niveauer. For det første skal udbydere af efter- og videreuddannelse udvikle og drive efter- og videreuddannelsesaktiviteter, som i endnu højere grad end tidligere er så tilpas fleksible, modulære og erhvervsrettede, at arbejdsmarkedets parter vil efterspørge dem på den måde og i det tempo, som de foretrækker. For det andet skal udbydere af efter- og videreuddannelse ikke mindst også fokusere på at udbyde dynamiske efter- og videreuddannelsesaktiviteter, som er udviklet og til dels drevet i samarbejde med aftagerne. Derigennem kan udbyderne høste fordelene ved en større grad af brugerinvolvering. For det tredje skal udbyderne af efter- og videreuddannelse udvikle og udbyde rigtigt forskningsbaserede uddannelsesaktiviteter for netop at sikre, at den seneste forskning og viden kommer kursisterne og dermed Danmark til gavn. For det fjerde skal universiteterne have meget kortere time-to-market, således at pludseligt opståede behov for specielle efter- og videreuddannelsesaktiviteter i for eksempel en specifik branche kan dækkes uden langvarigt udviklingsarbejde. Og endelig skal universiteterne sørge for at kapitalisere på de mange synergier, der opstår ved at udvikle og drive efter- og videreuddannelsesaktiviteter i samarbejde med aftagere i form af for eksempel større studenteroptag på de traditionelle dagstudier, ligesom de traditionelle dagstuderende i høj grad kan få gavn af input, erfaringer og viden opnået i forbindelse med efter- og 
videreuddannelsesaktiviteterne, idet mange undervisere på de højere læreanstalter heldigvis både underviser på dagstudierne og på efter- og videreuddannelsesområdet.

Disse udfordringer er som udgangspunkt både pædagogisk, forskningsmæssigt, administrativt og personligt interessante for de fleste dynamiske universitetsfolk, og dette bidrag vil løfte sløret for nogle af de strategiske overvejelser og mulige løsninger, som vi på Fakultetet for Sprog, Kultur og Kommunikation arbejder med og har til hensigt at afprøve.

\section{Nye tider - nye behov - nye overvejelser - nye løsninger}

På Fakultetet for Sprog, Kultur og Kommunikation har efter- og videreuddannelsesområdet i flere år af mange årsager ikke været særlig højt prioriteret. Dette fokus er så småt ved at skifte, og vi er en del, der arbejder på at opdyrke området.

Vi har som en del andre indset, at de nye tider har affødt en række nye behov hos aftagerne. Konventionelle kurser med to timer om ugen over fjorten uger er bestemt ikke længere det, aftagerne efterspørger. Aftagerne synes nu i endnu højere grad at efterspørge korte, koncentrerede og ikke mindst erhvervsrettede og kompetencegivende forløb, hvis relevans og indhold de både kan overbevise deres arbejdsgivere om, og som de kan bruge direkte i deres daglige arbejde i virksomhederne.

Desuden har aftagerne igennem flere år ytret ønske om langt mere fleksible og modulære forløb, som er så fleksible, at de kan tages i det tempo, som aftagerne ønsker, og ikke mindst sammensættes på den måde - og med den toning - som aftagerne ønsker. Derfor arbejder vi på Fakultetet for Sprog, Kommunikation og Kultur med en model, som danner basis for de langsigtede strategiske overvejelser.

\section{Porteføljemodel}

Som det fremgår af Figur 1 nedenfor, stræber vi efter at udvikle en lang række erhvervsrettede kurser, som aftagerne kan tage, enten som afsluttede forløb som korte kurser eller som en del af en decideret uddannelse som fagspecifikke kurser udbudt under en eksisterende mastereller kandidatuddannelse. Denne administrative distinktion er for aftagerne til dels ligegyldig for så vidt angår indholdet af det pågældende kursus, men det spiller en rolle i forbindelse med fastsættelse af adgangsbetingelser, udprøvning og type af bevis, der kan udstedes af udbyderen.

Denne fremgangsmåde anvendes til dels allerede i IT-Vest-sammenhæng, i hvert fald hvad angår modulariteten, og det synes at være en hensigtsmæssig tankegang. Figur 1 nedenfor illustrerer altså vores strategiske overvejelser om at på sigt at ville udbyde en lang række kurser, som det illustreres i venstre side af figuren. Disse kurser er til dels kurser, som er blevet specielt udviklede i samarbejde med aftagere, til dels eksisterende kurser fra de konventionelle dagstudier, som dog er tilpassede til målgruppen, og endelig helt nye kurser, som de mange forskningsklynger på Fakultetet for Sprog, Kommunikation og Kultur udvikler på basis af den seneste forskning.

Figur 1 nedenfor illustrerer også, hvorledes kursisterne på sigt vil kunne sammensætte en portefølje af kurser, som så, under forudsætning af, at VTU i højere grad vil åbne mulighed for at sammensætte en masteruddannelse på basis af indhold, således at en aftager vil kunne vælge en bestemt type kurser og dermed opnå en mastergrad i XX, efter aftageren naturligvis har udarbejdet en masterafhandling. Denne tankegang forudsætter til en vis grad også, at VTU vil anerkende denne valgfrihed og modularitet, og at ministeriet i højere grad end tidligere ikke kræver en fuldstændig færdigudviklet uddannelse, før den kan udbydes og senere føre til tildeling af en mastergrad. Denne tankegang kræver naturligvis også, at de kurser, som aftageren vælger allerede fra begyndelsen har været forankret i en eksisterende master- eller 
kandidatstudieordning. Større modularitet og bedre samspilsformer mellem teoretikere og førende praktikere er da også et af de konkrete løsningsforslag som VTU et al. (2006:2) peger på i deres rapport om udfordringer og løsningsmuligheder i forbindelse med de længerevarende uddannedes behov for efter- og videreuddannelse.

Figur 1 illustrerer desuden også en økonomisk måde, hvorpå de få ressourcer på det pågældende universitet kan anvendes. En forudsætning er naturligvis en række strategiske beslutninger om, i hvilken retning det pågældende universitet vil gå med dets efter- og videreuddannelsesaktiviteter, ligesom der skal træffes beslutning om, og allokeres ressourcer til, arbejdet med at udvikle og afholde kurserne af de sammensatte netværk og udpegede forskningsklynger.

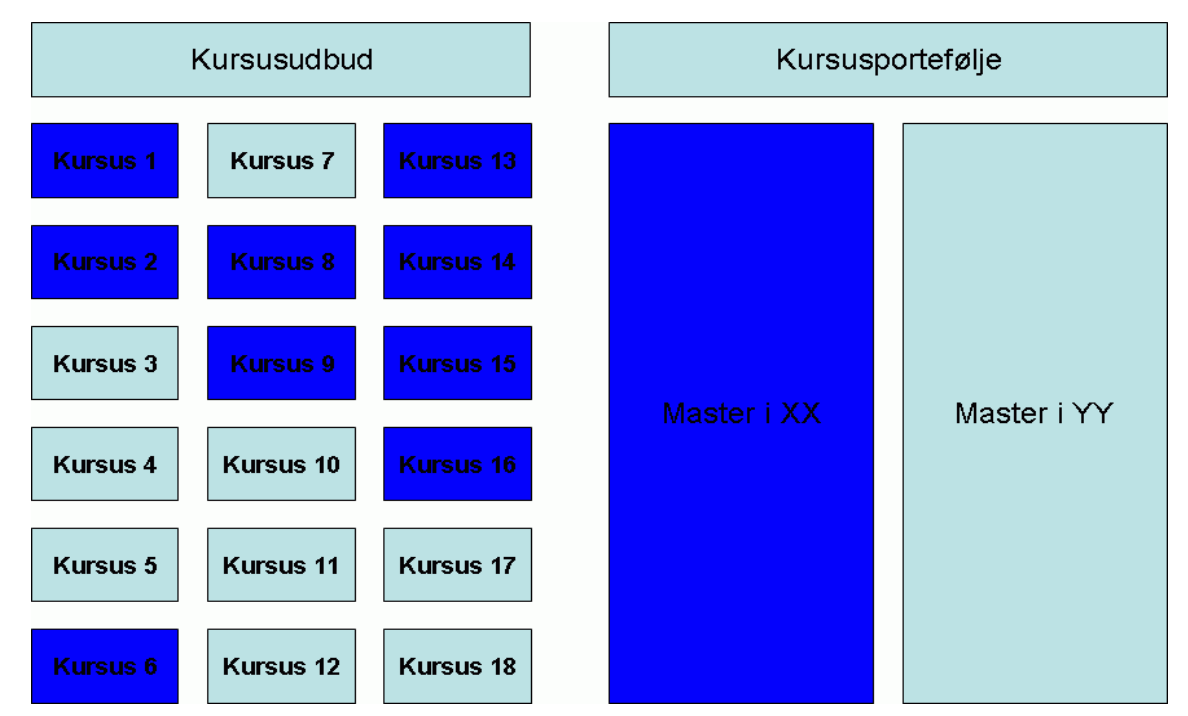

Figur 1. Porteføljemodel

\section{Kursusmodel}

Som det endvidere blev antydet i sidste afsnit er der også behov for nye pædagogiske overvejelser og løsninger. Her har vi på Fakultetet på Sprog, Kultur og Kommunikation for det første gjort os overvejelser om selve kursusformen, men også hvilket indhold kurserne skal have, ligesom hvem der skal levere indholdet af kurserne.

Indholdet af kurserne skal være erhvervsrelevant og meget gerne udviklet i samarbejde med netværkspartnere. Her er emner som professionel sprog- og kulturhåndtering højt på dagsordenen, ligesom naturligvis kurser i sprogteknologi spiller en stor rolle for vores fakultet. Desuden har vi en målsætning om, at indholdet af kurserne i højere grad end tidligere skal udvikles og leveres af de forskellige forskningsklynger, således at der sikres reel forskningsbaseret undervisning.

Selve kursusformen skal naturligvis også tilpasses kursisternes behov. Der har vi for visse typer af kurser arbejdet med nedenstående modeller. Kursusmodellen i Figur 2 nedenfor viser en løsning, man kan bruge for de kurser, hvor det er en pædagogisk fordel, at forløbet strækker sig over for eksempel seks uger. De fem lektioner kan med fordel placeres i perioden 1200-1800, således at kursisterne eventuelt vil kunne bruge formiddagen på forberedelse enten individuelt eller i projektgrupper, både hjemme og på campus. 


\begin{tabular}{|c|c|c|c|c|c|}
\hline Mødegang 1 & Mødegang 2 & Mødegang 3 & Mødegang 4 & Mødegang 5 & Mødegang 6 \\
\hline 5 lektioner & 5 lektioner & 5 lektioner & 5 lektioner & 5 lektioner & 5 lektioner \\
\hline
\end{tabular}

Figur 2. Kursusmodel med seks mødegange

Fordelen ved at mødes seks gange og over lidt længere tid end i de konventionelle kurser, er blandt andet, at man kan komme meget mere i dybden med de faglige diskussioner, ligesom det især i forbindelse med studenterfremlæggelser er en fordel, idet kursisterne mellem mødegangene skal ud i deres virksomheder og undersøge konkrete spørgsmål og derefter komme tilbage til kurset og fremlægge deres overvejelser og resultater i plenum. Dette er berigende for de fleste faglige diskussioner, og der er især i efter- og videreuddannelse meget at lære for alle parter, når kursister deler deres viden og erfaring.

En variant af kursusmodel med seks mødegange er nedenstående kursusmodel, som i endnu højere grad er baseret på tankegangen om endnu færre mødegange med flere lektioner og mulighed for mere intensivt socialt samvær. De to moduler bør med fordel være tidsmæssigt adskilt med ca. en måned og kursisterne kan med fordel få til opgave at løse en større opgave i tiden mellem modul 1 og modul 2. En af dagene på modul 2 kan så bruges til fremlæggelse/eksamen.

Modul 1

Modul 2

\begin{tabular}{|c|c|c|c|}
\hline Mødedag 1 & Mødedag 2 & Mødedag 1 & Mødedag 2 \\
\hline 8 lektioner & 8 lektioner & 8 lektioner & 8 lektioner \\
\hline
\end{tabular}

Figur 3. Kursusmodel med to moduler og fire mødedage

Ud over disse kursusmodeller er der naturligvis andre typer af kurser, hvor den mere konventionelle mødeform foretrækkes, f.eks. i forbindelse med mundtlige færdighedskurser, hvor der jo kræves en vis form for pædagogisk og faglig modningstid.

\section{Netværksmodel}

Som det også blev antydet i indledningen, har vi gjort os overvejelser om i endnu højere grad end tidligere at udvikle og udbyde kurser i tæt samarbejde med virksomheder, fagforeninger og organisationer i øvrigt. Som det vil fremgå nedenfor, har vi allerede indgået et sådant netværkssamarbejde med Forlæggerforeningen, jf. i øvrigt www.danskeforlag.dk. Dette netværkssamarbejde vil blive diskuteret nedenfor. De strategiske overvejelser går som sagt ud på at som organisation at kunne indgå netværk med flere skiftende netværkspartnere om et specifikt eller en hel portefølje af kurser. Desuden går de strategiske overvejelser også i retning af, at kurser i højere grad end tidligere skal udvikles og drives i samarbejde med aftagerne, hvilket både vil sikre et nødvendigt antal aftagere og ikke mindst et fagligt relevant indhold i kurserne for de pågældende aftagere. Samtidig vil netværkspartnerne og deres bagland i et vist omfang også kunne blive inddraget i selve kursusafviklingen i form af for eksempel udvikling og erlæggelse af undervisning. Dermed sikres en høj grad af bruger- 
involvering, hvilket i næsten enhver henseende er en fordelagtig fremgangsmåde, hvilket i øvrigt også diskuteres af Simonsen (2002).

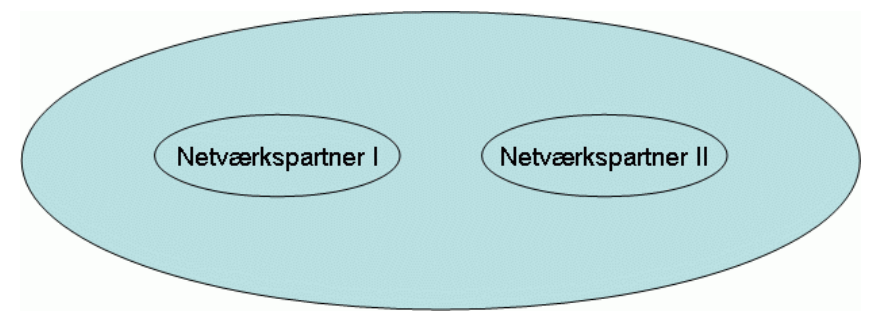

Figur 4. Netvcerksmodel med to netvœrkspartnere

Figur 4 ovenfor forsøger at illustrere denne tankegang, som i øvrigt også i den grad indgår i regeringens og ministeriets overvejelser om efter- og videreuddannelse, jf. i øvrigt VTU et al. (2006). I netværksmodellen ovenfor er der kun to netværkspartnere, men et netværk kan i teorien udvides til et ikke ubetydeligt antal af forskellige netværkspartnere, som hver i sær yder et bidrag til driften af et kursus eller en portefølje af kurser. Den netværkspartner, der er ansvarlig for selve administrationen og afviklingen af det pågældende kursus eller portefølje af kurser kan i princippet sagtens indgå i flere netværk samtidigt. Selve afviklingen af det pågældende kursus eller porteføljen af kurser foregår typisk på universitetet, men undervisningen kan i princippet sagtens foregå andre steder end på uddannelsesinstitutionen.

Netværksmodellen forudsætter naturligvis nedsættelse af en styregruppe med repræsentanter fra de to netværkspartnere. Denne styregruppe skal for det første udstikke rammerne for netværkssamarbejdet samt definere succeskriterier i samarbejde med den udpegede kursusadministrator, ligesom styregruppen bør følge den faglige udvikling, udpege fokusområder og prioritere disse, fungere som sparringpartner for kursusadministrator og dermed sikre en tilfredsstillende gennemførelse af efter- og videreuddannelsesaktiviteterne. Endelig vil styregruppen have den vigtige funktion, at den pågældende efter- og videreuddannelsesaktivitet forankres organisatorisk i de to netværkspartnere, hvorved mulighederne for både afvikling af kurset og sikring af det nødvendige antal kursister bliver forøget.

Hvordan alle disse strategiske overvejelser er forsøgt implementeret i praksis gives et eksempel på nedenfor.

\section{Netværkssamarbejde - et eksempel}

CBS og Forlæggerforeningen har i det sidste halve år arbejdet på at opbygge et netværkssamarbejde med henblik på udvikling og afholdelse af en portefølje af kurser inden for forlagsvirksomhed.

De to netværkspartnere i dette netværkssamarbejde er således CBS og Forlæggerforeningen. Netværkssamarbejdet tager mere og mere form, og de to partnere vil fra efterårssemesteret 2006 udbyde en portefølje af kurser med relation til forlags- og kommunikationsbranchen. Netværkssamarbejdet har indtil videre ført til udvikling af en portefølje bestående af tolv kurser, som Forlæggerforeningens medlemmer således kan søge. Det er således tanken, at porteføljen af kurser skal fungere som Forlæggerforeningens officielle efter- og videreuddannelsestilbud til medlemmernes ansatte, som typisk er akademikere med en humanistisk baggrund. Der har i flere år været et akut behov for en sådan uddannelse, og Danmark har til forskel fra mange andre lande som Sverige, England, USA og Italien ikke en decideret forlagsuddannelse i form af for eksempel en masteruddannelse i forlagsvirksomhed. Dette behov søges nu dækket ved i første omgang at udbyde to forlagskurser fra efterårssemesteret 
2006. Kurserne vil blive forsøgt afviklet som vist i Figur 2 og 3 ovenfor og vil i vist omfang blive forsøgt forankret i eksisterende studieordninger, således vi på lang sigt ikke udelukker muligheden for at kunne sammensætte en række kurser som en portefølje af kurser, der kunne danne grundlag for en ansøgning til ministeriet om at måtte få disse gjort til en del af en decideret masteruddannelse i forlagsvirksomhed.

Selve kurserne i dette netværkssamarbejde vil blive udviklet af de to netværkspartnere i fællesskab, men undervisningen vil foregå på CBS, ligesom matrikulering og anden administration varetages af CBS.

Netværkssamarbejdet er baseret på nedenstående model, som viser den praktiske organisation af netværkssamarbejdet.

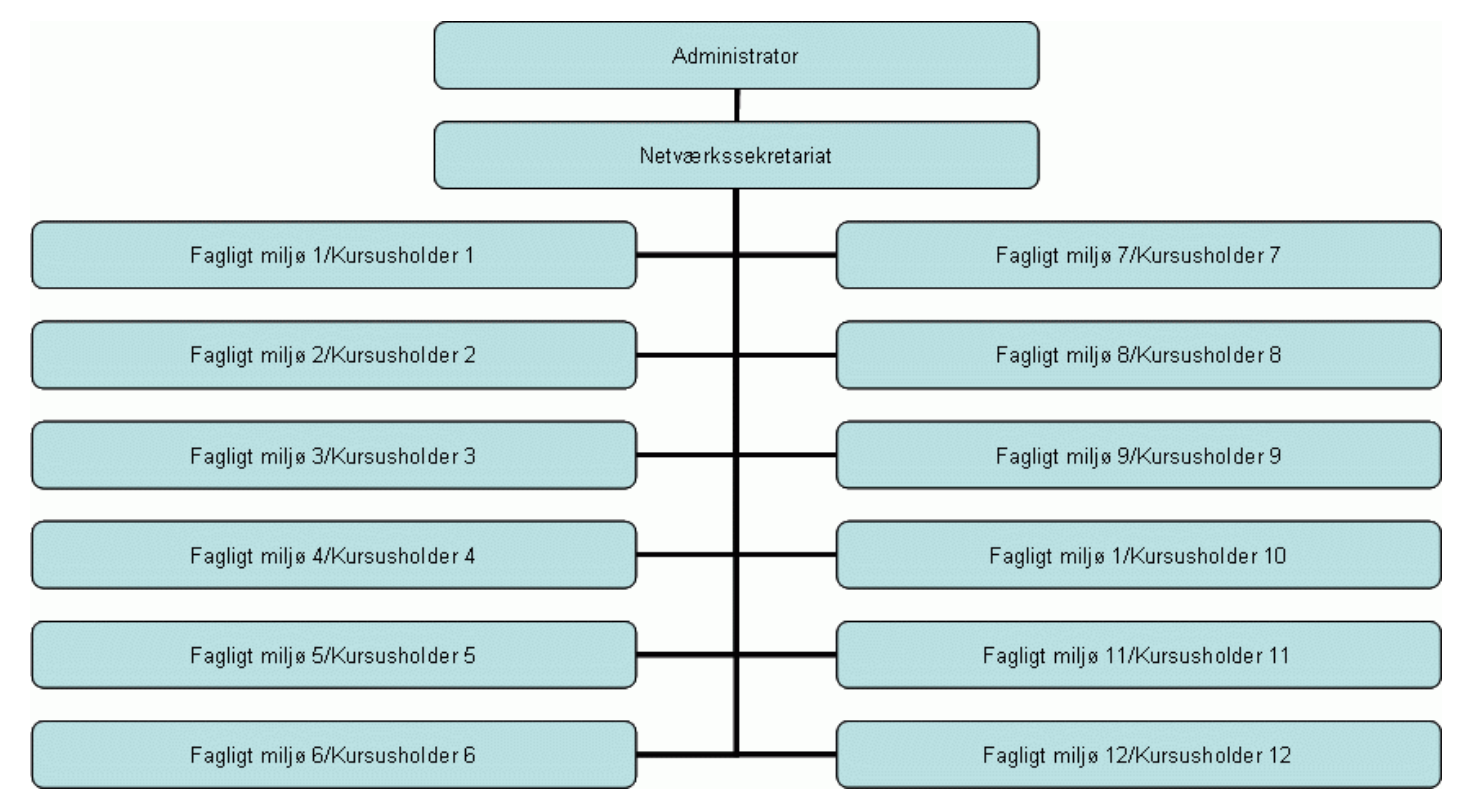

Figur 5. Organisation af netvcerkssamarbejde

Som Figur 5 viser, har vi udpeget en kursusadministrator og et netværkssekretariatet. Administrator planlægger den faglige gennemførelse af efter- og videreuddannelsesaktiviteterne og udpeger og træffer aftaler med de faglige miljøer og individuelle kursusholdere. Administrator er desuden ansvarlig for markedsføringsaktiviteter samt den daglige drift af netværkssekretariatet.

Netværkssekretariatet er ansvarlig for de daglige administrative opgaver i forbindelse med netværkssamarbejdet.

Selve undervisningen varetages af både interne og eksterne kapaciteter inden for de pågældende faglige miljøer/områder, og repræsentanter fra f.eks. Forlæggerforeningen vil således stå for vigtige dele af undervisningen, for eksempel i et kursus om "Branchekendskab", hvor nuværende og tidligere forlagsdirektører vil give eleverne (som er Forlæggerforeningens benævnelse for de nyansatte akademikere i forlagene) et værdifuldt indblik i forlagsbranchen. Tilsvarende vil eksperter fra CBS varetage undervisning i kurser som Sprogrigtighed, Salg og Afsætning og Oversættelse. De enkelte kursusholdere er således ansvarlige for planlægning og afholdelse af de respektive kurser inden for de rammer kursusadministrator har udstukket (om krav til for eksempel ECTS, studieordningsforankring samt udprøvning). 
Kurserne vil administrativt blive udbudt enten som Fagspecifikke kurser eller som Korte kurser afhængig af ministeriets svar på netværkssamarbejdets fælles ansøgning til VTU om midler til oprettelse af netværk om forskningsbaseret efter- og videreuddannelse, jf. VTU (2006).

De to netværkspartnere CBS og Forlæggerforeningen arbejder i øjeblikket på udviklingen af de to første kurser inden for forlagsvirksomhed, som udbydes på CBS fra efterårssemesteret 2006. Forlagskurserne kan med fordel søges af alle, der arbejder i forlagsbranchen eller i forlagsrelaterede brancher, som for eksempel kommunikationsbranchen, eller af andre, der til daglig arbejder professionelt med sprog, kommunikation og forlagsvirksomhed i bred forstand.

\section{Konklusion}

Dette bidrag har diskuteret en række strategiske og praktiske overvejelser i forbindelse med udvikling af efter- og videreuddannelsesområdet på Fakultetet for Sprog, Kultur og Kommunikation på CBS. Bidraget har desuden givet en række konkrete forslag til nogle modeller, som vi vil forsøge at bruge som udgangspunkt i forbindelse med udvikling og udbud af efter- og videreuddannelsesaktiviteter, og der blev givet et eksempel på et konkret netværkssamarbejde mellem CBS og Forlæggerforeningen.

Hvorvidt disse overvejelser er nok, vil tiden formentlig vise, men der er nok ingen tvivl om, at behovet for efter- og videreuddannelse vil være stigende i samfundet, og dette behov vil vi være med til at dække ved at udvikle og udbyde erhvervsrettede kurser, som i højere grad end tidligere er baseret på pædagogiske principper og overvejelser, som har gået sin sejrsgang på blandt andet Harvard og flere MBA-uddannelser, og som i højere grad end tidligere er udviklet i samarbejde med dem, der skal aftage kurserne. På den måde sikres en optimal vidensoverførsel mellem forskning og praksis, og devisen om, at der ikke findes god teori uden god praksis gælder i særdeleshed også i forbindelse med efter- og videreuddannelse. Og efter- og videreuddannelsesaktiviteterne kan dermed bidrage til udvikling af både forsknings- og praksismiljø - og denne gensidigt frugtbare dynamik kan komme hele det danske samfund til gavn.

\section{Litteratur}

Politiken.dk. 27. marts 2006 ”Danskerne vil have efteruddannelse”. <http://politiken.dk/VisArtikel.iasp?PageID=444201\&TemplateID=15410.>

Madsen, Tanja Nyrup og Redder, Gitte. 27. marts 2006 ”Danskerne klar til at spare op til uddannelse”. UgebrevetA4. Online <http://www.ugebreveta4.dk/smcms/Ugebrevet/10046/10603/10611/10634/Index.htm?ID=10634>

Simonsen, Henrik Køhler (2002): User Involvement In Corporate LSP Intranet Lexicography. In: Lexicographica - Series Maior. Proceedings of the Eleventh International Symposium on Lexicography, May 2-4, 2002 at the University of Copenhagen (Edited by Henrik Gottlieb, Jens Erik Mogensen and Arne Zettersten), pp. 489-509.

VTU. 27. marts 2006 “Midler til netværk om forskningsbaseret efter- og videreuddannelse” <http://vidensamarbejde.dk/portal/page?_pageid=39,62608\&_dad=portal\&_schema=PORTAL>.

VTU et al. 27. marts 2006 “De længerevarende uddannedes efter- og videreuddannelse - aktuelle udfordringer og løsningsmuligheder med fokus på universiteterne”, <http://www.videnskabsministeriet.dk/fsk/div/unisoejlen/efterogvidereuddannelse.pdf> 